\title{
THE MYTH OF SAYYIDINA ALI'S “ILLEGITIMATE CHILD" CROCODILE: The Phenomenon of Syncretism Among Coastal Communities in West Kalimantan
}

\author{
Eka Hendry Ar. \\ Pontianak State Institute of Islamic Studies \\ Email: ekahendry77@gmail.com \\ Ria Hayatunnur Taqwa \\ Pontianak State Institute of Islamic Studies \\ Email: ria.taqwa@gmail.com \\ Syf. Fatimah \\ Pontianak State Institute of Islamic Studies \\ Email: fatimahabubakar@rocketmail.com
}

\begin{abstract}
West Kalimantan has various local cultural treasures in the form of ritual traditions, arts as well as oral traditions in the form of pantun, abstinence, legends, and myths. The cultural treasures spread throughout the West Kalimantan regions, one of which is found in the coastal area of the Province. The treasure that attracts the attention of the researchers is the oral tradition of the myth found in coastal areas of Kubu and Teluk Pakedai. The myth is the crocodile of anak kampang Sayyidina Ali (Sayyidina Ali's "illegitimate child"). This myth contains many dimensions, ranging from the dimensions of local culture and religious views to syncretism. The researchers also assume that the myth contains a negative stereotype against Shia. This research attempts to reconstruct the culture of the myth in various spectra. This research uses ethnography method. It reveals some interesting aspects such as euhemerism of the figure of Imam Ali. The myth also contains a very strong syncretic content, thus arising a paradox of the existing character, between glorifying and degrading. It arises because of a thorough understanding of the history of Islam on the one hand, and the strong style of local tradition held by the community on the other. However, the myth is quite functional for society, because it indirectly instills awareness about nature conservation. Finally, in relation to the allegations of political motives in myth, the researchers found no sufficient data, but the academic suspicion of the researchers had a strong belief in it.
\end{abstract}

Keywords: myths, syncretism, euhemerism, mithologization of figures, negative stereotypes, political myths, conservation. 


\section{INTRODUCTION}

West Kalimantan, in addition to having a wealth of natural resources, also has a lot of wealth of cultural treasures. The local cultural wealth possessed in the form of regional arts, cultural rituals (including religious rites), and oral traditions such as legends and myths. This wealth reflects that this area has a wealth of culture (in the form of values, norms and artifacts) of the past which actually reflect the identity of the people of West Kalimantan. Each region has its own cultural characteristics, be it hinterland people who inhabit thousands of rivers in area or the wilderness that was once often illustrated as "the virgin of Borneo". This geographical location of course affects the patterns of relations between humans and nature, that subsequently form the cultural characteristics.

In the context of this study, the researchers are interested in researching one of the cultural treasures of myths that developed in the coastal region which is the myth of the crocodile of Sayyidina Ali's illegitimate child. This myth is found around the coastal areas of Kubu Village and Teluk Pakedai Village (both now being parts of Kubu and Teluk Pak Kedai sub-districts). This myth attracts the researchers' attention because it suggests an academic controversy and academic prejudice of the ideas and motives behind it. Considered controversy because in terms of theological and local customs, the term anak kampang is a negative term meaning illegitimate child. On the other hand, the attribution of the name of Sayyidina Ali (who in fact is the name of the fourth Caliph of Islam) is a figure highly respected by the Ummah in that myth. It causes academic prejudice, perhaps it has something to do with hateful residues or at least a theological contradiction between the Sunnis against Shi'a. Is this myth created in order to form a negative streotype against Shi'a?

In this light, this research focuses on the social contruction of the crocodile myth of Sayyidina Ali. Then what is the motive behind the birth of the myth? Does it have anything to do with religious hatred against Shia. How is the process of interaction between the concept of cultural society and religious views that exist in the myth? Finally, what practical values are founded from the belief in the myth? This research is expected to understand the cultural construction of the myth of Sayyidina Ali. This study also aims to explore the motive of the birth and development of the myths in both communities. In addition, it aims also to prove the presumption that there is a motive of religious hatred against Shia. Through this research, it is also expected to get a picture of the process of interaction between the concept of culture with religious views (especially Islam) as well as practical advantages resulting from the belief in the myth to the local community. This research uses qualitative 
approach, with Max Weber's interpretive paradigm. The method used is ethnography (A. Latief Wiyata, 2002: 23; James P. Spradley: 1997: 3). This study uses two perspectives, namely emic and ethics. Emic aims to describe the socio-religius phenomenon from the point of view of the cultural actors investigated. While ethics is the result of the interpretation of the researchers to the perspective of cultural emic perspective or its native speakers.

This research is a study of the dynamics of Islam and local culture. Therefore, in addition to understanding the case of the myth specifically we need to also understand macro construction of the study of Islam and local culture. There is a number of studies on local Islam by Clifford Geertz (1981), Muhaimin, M. Alifuddin (2007), Budiwanti (2000) and Nur Syam (2005). Clifford Geertz conducted research on Javanese Islam, Muhaimin studied Banten Islam, M. Aliffudin studied Buton and Islam Budiwanti about Wetu Telu Islam in the Bayan community in Lombok (West Nusa Tenggara). Meanwhile Nur Syam (2005) studied coastal Islam in Tuban area of East Java, Clifford Geertz, the Religion of Java (1981), discussed Abangan, Santri, Priyayi in Javanese Society in the mid-1950s in a small village in East Java, the village of Modjokuto. Geertz described the characteristics of a community in Java, which he classified into three groups: the santri, abangan and priyayi. The Javanese religion is generally syncretic.

Geertz's theory was criticized by Muhaimin and Nur Syam. According to Muhaimin, Geertz's study of Javanese Islam represents the perspective of Islamic studies based on the premise that the influence of Islam in Java is weak and only skin deep. Muhaimin holds that, Islam in Java is actually similar to Islam elsewhere, namely Islam in the local cultural framework. According to Woodward, Islam in Java is not a syncretic, but it is a typical Islamic prototype, that is Javanese Islam. Budiwanti (2000) conducted on Sasak Islam in Bayan Village namely Wetu Telu rite which is a syncretic Islam with Hindhu traditions. Worship rites tinted with local style and "deviating" from shariah are generally practiced by Muslims in the Indonesian Archipelago, like code of dress, prayer time and ordinance that accompany the rituals.

In the local context of West Kalimantan there are several studies on myths, such as the research by Stepanus, Ahadi Sulisssusiawan and Sesilia Seli on prohibitions in Dayak Sunkung Community of Siding Subdistrict of Bengkayang Regency. Prohibition is part of a growing myth in society, not just the Dayak community. The same can be found in the Malay Community such as Eka Hendry's research on the Values of Islamic Education among Pontianak Ethnic Malay (Ar., 1998), Marisa Syakirin on prohibition in Sambas Culture, Ibrahim MS. on Communication Wisdom in the prohibition among the Malay 
in Jajang. These studies show the forms of prohibition found among various tribes in West Kalimantan and the function of such prohibition in society. The study of Stepanus et al., examines the meaning, functions of the position of prohibition in Dayak Sungkung society with sociolinguistic approach. This study concludes that prohibition has the deepest meaning that serves as a socio-cultural teaching, rebuke, advice and guidance of life. Further, this study concludes that, prohibition can be classified into aspects such as salvation, relation to time, place, sex and occupation.

This research highlights the acculturation between local religions and cultures, which then form religious models with local features, such as syncretic beliefs. There are several studies with a view of the pattern of local Islam that is not synonymous with syncretism, but is a feature of local Islam. However, most of the results of acculturation between Islam and local culture gave birth to a syncretic religious pattern. The birth of the myth of crocodile of Sayyidina Ali's illegitimate child according to the researchers can be seen in the pattern of syncretic acculturation.

\section{MYTHS IN THE INTERACTION BETWEEN ISLAM AND LOCAL CULTURE.}

The word myth comes from Greek, musteion which means closing the mouth or the eyes (Karen Armstrong, 2013: 35). This word has something to do with obscurity and darkness, so it needs to be expressed in order to understand it. Usually, it often overlaps in the use of the terms myth, legend and fairy tales. William Bascom, (in Mariasusai Dhavamony, 1995: 147) distinguishes between the three, as shown in table 1. Bascom's division needs to be criticized, because of the fact many myths are about humans. In fact, myth and legend are almost similar, although there are some parts that may be different. The similarity is that all three (myths, legends and fairy tales) are part of an oral tradition in the form of description of stories passed from one generation to the next before being written in the holy books. The narratives contain cultural phenomena of a society and provide an indirect education to the audience as well as local identity (Prasojo, 2012). In addition to the narrative of the story, sometimes the myth may also includes statements, stories or a drama plot (Mariasusai Dhavamony, 1995: 147). 
Table 1.

Differences between Myths, Legends and Fairy Tales by William Bascom

\begin{tabular}{cccccc}
\hline Form & $\begin{array}{c}\text { People's } \\
\text { perspective }\end{array}$ & Time & Place & Characteristics & Main figure \\
\hline Myth & $\begin{array}{c}\text { Regarded } \\
\text { as fact }\end{array}$ & $\begin{array}{c}\text { Far in } \\
\text { the past }\end{array}$ & $\begin{array}{c}\text { World of the } \\
\text { gods, other } \\
\text { world }\end{array}$ & Sacred & $\begin{array}{c}\text { Not humans; the } \\
\text { gods or other } \\
\text { beings }\end{array}$ \\
\hline Legend & $\begin{array}{c}\text { Regarded } \\
\text { as fact }\end{array}$ & $\begin{array}{c}\text { Not far } \\
\text { in the } \\
\text { past }\end{array}$ & Current World & Profane & Humans \\
\hline $\begin{array}{c}\text { Fairy } \\
\text { tales }\end{array}$ & $\begin{array}{c}\text { Regarded } \\
\text { as being } \\
\text { made up }\end{array}$ & $\begin{array}{c}\text { Any } \\
\text { time }\end{array}$ & Anywhere & Not sacred & $\begin{array}{c}\text { Can be humans } \\
\text { or other beings } \\
\text { or objects }\end{array}$ \\
\hline
\end{tabular}

Source: James Bascom (in Mariasusai Dhavamony, 1995: 147).

Mariasusai Dhavamony (1995: 147) by quoting Bronislaw Malinowski also distinguishes between myths, legends and fairy tales. According to B. Malinowski, a myth is "a statement of a higher and more important truth about the reality of origin, which is still understood as the pattern and foundation of primitive life. Meanwhile, according to C.A. Van Peursen (in Hairus Salim, HS., (?), a myth is a story that gives certain guidelines and directions to a group of people. Furthermore, it is said by that a myth tells how a state becomes something else or in other words it talks about something extraordinary. The actors in a myth usually include the gods or supernatural beings. Through myths, we will learn the secrets of the origin of things, be able to enter into the living relationships with them to enable them to recreate the original order of things as they begin to degenerate, or to make them appear again as they begin to disappear. Therefore, myths are sometimes far more true, compared to legends and fairy tales.

A myth is expected to reveal some aspects of life that cannot be easily expressed in discursive logical words (Karen Armstrong, 2013: 35). Armstrong came to the conclusion that, a myth is a human effort to be able to explain a deeper significance of an event they face. The opinions are more or less the same, as Levi Strauss noted. According to Levi Strauss (in Ahimsa-Putra, 2001) myths have unrelated units of relations, but are unity of relations that can be combined and used to reveal the meaning behind them ${ }^{1}$. Further Levi Strauss (in Ahimsa-

1 Levi Strauss is a proponent of structuralism. His analysis of myths has been very much influenced by linguistics. There are several assumptions about why language is used as the foundation for understanding myths. First, fairy tales, ceremonies, kinship and marriage systems, patterns of dwellings, clothing, etc., are formally regarded as languages, or devices of symbols and signs that convey certain messages. Second, the proponents of structuralism assume that in man there is a genetically inherited basic ability, to reconstruct a structure on 
Putra, 2001: 94) set the foundation for structural analysis of myths. First, if the myth is seen as meaningful, not found in its own independent elements, separate from each other. The meaning is formed from a combination of these mythical elements. Second, although myths belong to the language category, they are not just a language. Each of them (read: myth and language) shows its own characteristics. Third, these characteristics are found not at the level of the language itself but above it. These characteristics are more complex than language features. In other words Levi Strauss (in Ahimsa-Putra, 2001) stated that, social-cultural phenomena that express art, ritual, and life patterns are representations of outer structures that describe the human mind.

In relation to the mythical function, according to Annemarie de Waal Malefijt (in Hairus Salim HS., (?), it can be a double war, on the one hand as a unifying force in society, while on the other hand it can also be a breaking power. C.A. Van Peursen (in Hairus Salim HS., (?), explained more clearly about the three mythical functions namely; first, to make people realize that there are magical powers. Second, myths provide a guarantee for today's life. Third, as an intermediary between man and the forces of nature. Another opinion of LeviStrauss (in Yoseph Yapi Taum, 2011), the function of the myth is a logical tool to explain the various contradictions experienced by humans.

Based on the above theoretical studies, it seems that the myth of Sayyidina Ali can be understood that it has something to do with certain beliefs or religions. The level of community confidence is relatively higher compared to the existing legends and fairy tales. Primitive societies up to now believe this myth as a truth inherited from their ancestors, which then affect their attitudes and actions. The mystery of the illegitimate child may be as follows; To illustrate the past, the disclosure of human helplessness to understand their nature and can also be a particular hegemonic instrument of power (J. Van Ball, 1987). This ilustration has also been found both in the worlds of Islam and the West as mentioned by Abdulroya Panaemalae, A., \& Prasojo, Z. (2016).

\section{MYTHS ABOUT ANIMAL RELATIONS AND ALI IMAM}

The myth of Sayyidina Ali is an old one and is no longer popular. Jaja said that, this myth has long been around, but now rarely known by the younger generation. Associated with the version of the story, there are several versions between one area and another. The version encountered in Olak-olak Kubu, as Jaja (not real name) reported as follows:

the symptoms encountered. Third, in understanding a phenomenon, the synchronic aspect is placed before the diachronic aspect. Fourth, the relations within the structure can be simplified into binary opposition (Ahimsa-Putra, 2001). 
"Sayyidina Ali is known as a very fierce or courageous figure, so all the supernatural sciences are always associated with him. In the past, the sciences were known as science Sayyidina Ali's sergah (shout). This science in dade dolo'-dolo' (science in the chest of the ancestors) is the term used by Mr. Jailani. Because Imam Ali was so mighty, it is believed that his sperm was a miracle that could be tembalau (glue) to the handle of a machete. "Daki (dirt) 'from Imam Ali's genitals can be used as tembalau, so mighty he was" (Jailani's account). The faith in Imam Ali is famous all over the place, and makes many people idolize him, even dream of being able to become his partner. To sum up the story, there was a woman (Pak Jaja could not explain who the woman was) who was so infatuated with Imam Ali that she kept a small knife whose handle was glued with a Imam Ali's sperm. The knife placed on the abdomen was imagined by the woman as if Ali had consummated her. Because of a miracle, the glue finally melted and flowed into the woman's genital. With the power of Allah ta'ala, eventually the woman was pregnant. When she knew she was pregnant, the woman was embarrassed, because she had no husband, but she was pregnant. “

To this point, there is a missing link of the story, because the respondent could not detail the process.

"To sum up the story, something was thrown by the woman from her genital, so it was later believed to be a crocodile. Then, the crocodile was called the illegitimate child of Sayyidina Ali."

This belief by the community in the past was usually practiced to find out whether a captured crocodile was alive or dead; people used to take the oath of Imam Ali. The oath goes as follows; "If you do not wake up, you are not the illegitimate child of Sayyidina Ali." So usually after reciting the oath, the crocodile moves. This happens according to Jailani because the crocodile knows the cause of its origin, and it is ashamed if it is not regarded as the offspring of Ali ". So, this oath is always used by the community to ensure if a captured crocodile is dead or not." Another version accounted by Long Tam (not his real name, 53 years of age), born and grew up in Teluk Pakedai, about 10 years into a fisherman (looking for shrimp). Here is his narrative:

"When I was a little boy, my grandfather used to tell stories. One of them was about Sayyidina Ali's illegitimate child crocodile. Once, Siti Fatimah wanted to drink young coconut water. While the coconut tree was only found in the middle of the sea where the kafeer genie lived. To get the fruit, one must stay on the island, so Fatimah went there 
by riding a buroq. After returning from the place, Fatimah suffered a miscarriage. The blood of her miscarriage was thrown into the sea. It swam with like jelly fish. The blood then turned into a crocodile. This crocodile swam in the sea and finally was caught the fish net belonging to King Mina. On Friday, King Mina lifted the fish net because the fish also wanted to perform Friday prayer. When the net was lifted, the King saw a strange animal but still small. Finally the animal was kept by King Mina until it grew bigger. The animal could talk and asked King Mina, "Where are my parents?" King Mina said, "Swim to where the sun rises." Upon Arriving at the place, the crocodile said, I am looking for my parent, Sayyidina Ali." Finally a fight occurred between Sayyidina Ali and the crocodile. Both of them were strong. The crocodile then said to Sayyidina Ali, "Where is my mother?" Then came Siti Fatimah. She was having her period, and sitting on the beach on a banana leaf. The crocodile licked Fatima's body like a child caressing his mother. The crocodile also licked the blood on the banana leaf. Fatimah was angry. You're a nasty crocodile!" Finally the crocodile asked Fatimah, "What's my name and what must I eat?" Fatimah replied, "If you wanna know, stick your tongue out!" Then Fatima cut the crocodile's tongue. "Your name is crocodile," said Fatimah. Since then, the animal was called crocodile had no tongue anymore".

Long Tam's version of the story with the Arab world setting explicitly seems contradictory. The interesting side of the Long Tam's version, although he admitted it is just a story, a fairy tale of a bedtime story, in the end he acknowledged that, "I use this spell". That is in certain circumstances he uses the spell for practical purposes. According to Long Nan, he has been working to find shrimp for about 10 years. Usually, if the area has a lot of shrimps, there are usually (many) crocodiles. Therefore, the risk of shrimp fishing is higher, because usually we encounter crocodiles. So, sometimes he uses this advice, namely "I know you are King Mina's pet, I am a descendant of King Mina". According to his confession, in addition to reading this mantra, he also uses knowledge in the Quran, and praise be to Allah for 10 years he was never disturbed by crocodiles.

There are also other versions, according to Kucung (not his real name, in his 40s) from Tanjung Satai North Kayong. In Satai, the myth is also around with a slightly different version. The version found in Satai is the sperm of Sayyidina Ali which is cleansed by a twig, then if it is thrown into the water then it becomes a crocodile. Whereas if thrown to the land, then it will become another animal that creeps on land like a snake. The semen comes out of Ali's genital. According to Kucung, this myth is usually popular in areas of people who believe that it has a bearing with crocodiles, as in the case of 
twin crocodiles or those who consider themselves having twin brothers who are none other than crocodiles. In relation to Kucung's revelation about the possibility of a myth developing in an area containing myths about crocodiles, the researchers found in the Olak-olak Kubu area there are indeed crocodile twin myths. One of them is the 'Cincin' legend.

Cincin is the name of a crocodile which is a twin of a human child named Long Limin (not his real name). According to Jaja this is not a myth, but a real story, because the descendants of Long Limin are still alive. The age of this legend is about 105 years, based on the age of Long Leman who is approximately the age of the deceased parents of Jaja. It is said that the parents of Long Limin gave birth at night (at that time there was no electricity), but strangely besides the human child also came out a lizard, but the size smaller than the gecko. Some relatives get dreams that the lizard is not thrown away, because it was the sibling of the newly born baby. The gecko asked to be raised. Briefly, when this crocodile has grown larger, the family had a dream that the crocodile asked to be released into the sea. He advised her family not to break up the relationship with her, and if they needed assistance related to a sea-related disaster, he would help. Finally, this crocodile was released to the river, and named Cincin. It is said that if still alive, Cincin is very large, and among the crocodiles in the Kubu River are believed to be the offspring of Cincin. Therefore, to catch a crocodile in Kubu, one should consult the village shaman, whether it is the offspring of Cincin or a common crocodile.

It is believed that there was once a disaster happening to a man named Amat Kaloi (not his real name) who caught a crocodile with an aler (fishing rod). It turned out that the crocodile captured and killed was believed to be a descendant of Cincin. The crocodile was sold by Amat Kaloi for IDR 6 million, at that time the amount was big enough according to Jailani. As a result, Mat Kaloi suffered from the same disease suffered y the crocodile. So the money for treatment was greater than the sales of the crocodile. Finally Amat Kaloi died with this mysterious illness. Based on this story, the public is quite careful in the affairs of catching crocodiles, so as not to catch the offspring of Cincin.

The myth of crocodiles is also growing, in which implicitly there is a fear in the community of the threat of crocodiles. The myth is linked to the hostility between cats and crocodiles. Older people believe, according to Jaja, that the mortal enemy of crocodiles is the cat, then Jaja said:

"Do not try to take a cat with you when fishing, because it may anger crocodiles". 
According to people's belief in Olak-olak Kubu, a dying crocodile if stepped over by a cat can anger the crocodile. Even myths developed among older people when eating, between the lamp and the rice when passed by the cat, then they do not want to eat the rice. According to the belief, the shadow of a cat may have bad luck on the person because the shadow of the cat will become our shadow, so crocodiles see the shadow of a cat on us.

\section{MYTHS ASSOCIATED WITH SAYYIDINA ALI}

In addition to the myths that link animals and Sayyidina Ali, there are also a lot of supernatural powers or martial arts associated with Sayyidina Ali. Brahim (not his real name, aged 39) admitted that his ancestors had the tradition of "crocodile supernatural power". According to his explanation, there is a link between supernatural power and Sayyidina Ali because Ali is known by local people as a friend who has a variety of supernatural powers. According to Brahim, he has heard and learned several things such as the sergah supernatural power of Sayyidina Ali, Sayyidina Ali's Chain and Sayyidina Ali's martial arts.

Sergah Sayyidina Ali is a supernatural power to paralyze the opponent by using a shout. According Jailani this is a supernatural power that was taught by older people the old time that serves to paralyze the opponent. According to Jaja it is"the power in the chests of the ancientors. The effect of this power can lead to break the bile. He reminded to be careful with this power, because if not careful in its use, it may affect one's own child. Sergah Sayyidina Ali is a power to weaken the opponent, especially when we are in a state of threat or there are others who threaten our safety. According to Jaja, this power requires certain exercises. For example, every time we wake up, we wash our eyes with water as much as possible by reading the mantra "Nursilah terbelah terjadi terjadu" (Nursilah be split and it happens)". With consistent practice, then we will have that power, which can at times be used to maintain the safety of ourselves and others.

A slightly different version of sergah Sayyidina Ali also exists and is practiced by the people of Teluk Pakkedai, as described by Brahim. According to Brahim, Sergah Sayyidina Ali is a supernatural power. While recalling, Brahim recited in Arabic, "Allah rabbana wa rabbukum, lana a'malana wa lakum a'malakum, Allah ashfiq ". There is also the power of Rantai Sayyidina Ali (Sayyidina Ali's Chain). Brahim demonstrated some forms of its movement by wrapping both hands to the nape of the neck and several other movements. Brahim admitted he had forgotten most of the movements, because he is no longer practiced the power. The chain of Sayyidina Ali is believed to be supernatural power that makes a person immune. Besides the chain of Sayyidina Ali, there is also the silat (martial arts) of Sayyidina Ali. 
The association of silat with Sayyidina Ali is allegedly due to the assumption that Ali had extraordinary power. In fact its form is ordinary, like any other martial arts but usually coupled with Karin or Syeikh. It also comes with some mantras that must be practiced for the martial arts to be stronger by fondling hands with incense while reading incantations:

\author{
"The treads of Prophet Solomon" \\ The movements of Prophet Muhammad \\ Silat of Sayyidina Ali \\ The flash of Gabriel"
}

The above mantra mentions the name of Sayyidina Ali because of his might. Then the blow speed is associated with Gabriel's flash. Gabriel is likened to a symbol of speed in the martial arts movement.

\title{
BACKGROUND OF THE ORIGIN OF MYTHS ABOUT CROCODILE TWINS
}

The event of crocodile twins is a myth perceived diversely by society. According to Brahim, this story is an unseen phenomenon where interaction occurs between humans and jinn. "In fact, it incarnates like a young lizard that comes out together with the process of giving birth to a human child that is a Jin that resembles the lizard. That is actually the scientific explanation of the phenomenon of the birth of twin crocodiles," Brahim explained. However, many believe that this phenomenon is real and happens in the middle of society. The researchers saw a teacher who is a descendant of the king of Sekadau Kingdom experienced kesarong buaya (possessed by crocodile). His movements were terrifying, like a crocodile, trying so hard to get to the water. His body was slimy, and made a frightening hissing sound. Some adult males sometimes could not handle him, so more people needed to calm him down. To heal him, people called upon one of his relatives. Some mantras were read, and some foods or offerings were thrown into the river, then he recovered.

Other places also have more or less similar stories. However, the attributions are diverse. Some are attributed to the history of certain kingdoms, and some lsso associated with certain ethnicities. Similar myths can also be found in the Teluk Pakkedai. This myth is thought to have something to do with Bugis culture. Based on the experience of living in the midst of Bugis community in Teluk Pakkedai, according to Brahim, Bugis people have many beliefs that come from their ancestors. It is said that, according to Brahim, these myths are derived from the classical Book La Galigo. Christian Pelras (2006: 101) acknowledged that the relation between man and nature has given birth to many myths, including the myth of the origin of nature and its contents as 
found in the mythical literature of La Galigo in the Bugis society. The idea of the Dewata Sisine (The One God)) and the concept of 7 layers of the sky (langi'), earth (tana), 7 layers of the underworld (peretiwi or uri' liung / buri' liu) and the names of the gods associated with nature. Similarly, there are myths about natural events in ethnic Dayak of Iban, Kanayant, Kenyah and Ngaju (Paulus Florus et al., 2005). These mythologies describe the concept of human relationship with nature (land, water, forests and rivers).

According to Brahim, the Bugis believe that, every birth of a human child is usually followed by four twins or brothers, namely, blood that later becomes heaven (mallajang), water (mengalere' / flowing), placenta (soil) and blood (tambuniah). The term of the four elements is uri' uria tembuni' tambuniah. Uri' (skin wrapping the baby), uria (amniotic fluid), tembuni' (placenta) and tambuniah (blood). So in society, there is a term, the baby born with water twin or blood twin. These four brothers are transformed into various forms, some are the people of heaven (malajjang), and some become crocodiles i.e. water twin. Each of these twins must be fed. The food is 4 types of sticky rice: white, black, red and yellow, arranged in a dish in an opposite position, white with black, red with yellow, with an egg placed in the middle. This sticky rice is placed above the house (in para-para') and some is thrown into the sea.

Each incarnation has a king, such as the Crocodile King named Tadam Paling and Heaven King named Daeng Mudiring. His family, especially his grandfather strongly believes that these ancestors must be respected and fed through the Pandre Dewata ceremony (offering to the gods). Because based on experience, these ancestors in times of need will be able to provide assistance to their descendants. Based on the story of his predecessors, Ibrahim explained that, in everyday life, during difficult times such as fights, where his grandfather was in danger, being chased by enemies until he had to pass through the stream, Tadam Paling was called upon, then later on the stream crocodiles lines up and became the savior of his grandfather to escape to the other side of the stream. Then, when paddling the boat, often the people first asked for help "family" in the sea that is crocodile, to help push the boat, so quickly get to the destination. The story is more or less the same, also presented by Jailani. According to Jailani the offspring of Cincin may help in the event of calamity in the River Kubu, as there are people lost in the river, then Cincin or his offspring will provide assistance unseen.

Then the kinship between the Bugis and the crocodiles is quite strong, so as far as Ibrahim knew, the people of Teluk Pakedai almost never hunt crocodiles, especially the ethnic Bugis. Because they strongly believe that crocodiles still have family relatition with them. And there is also a belief about the power 
associated with crocodiles, such as the immune power. According to the beliefs of society, Ibrahim expleined, the immune power originally came from the power of crocodiles. Because as we know, the crocodile has very thick skin and cannot be penetrated by any weapon. The only weakness of the crocodile is its eyes, therefore to conquer the crocodile, one can attack its eyes. The position of crocodiles is highly respected. To distinguish between the incarnate crocodile that has a kinship with humans, and a wild crocodile can usually be distinguished from its finger. If it has 5 fingers, it is an incarnate crocodile, while if it has 4 , then it is a wild crocodile. A wild crocodile is more virulent than the incarnate, while the incarnate crocodile is believed to be not malignant and will not attack humans, because there is an agreement between man and the crocodile, Ibrahim explains.

In addition to transforming into a crocodile, the heavenly brother of humans incarnates in the form of a snake. The supernaturalpower of snakes is associated with poisonous venom commonly supplied to cudi' (traditional Bugis weapons in the form of small knives) and sacred spears commonly known as Besi Sembiring for the spear and Besi Lu' to make cudi'. It is believed that the khadam or kari of poisonous weapons is a snake which is the incarnation of the twin brother of humans.

\section{Mithologization of Figures: Form of Glorification (Euhemerism) of Figures}

Based on a study of the content of crocodile myths and attribution of supernatural power to Imam Ali, the researchers observed that there is a process called euhemerism or historical interpretation. The theory of euhemerism ${ }^{2}$ states that, myths are records of exaggerated historical events. Based on the theory, the story tellers gain the equivalent status of the gods. This theory is in line with the theory put forward by J. Van Baal (1987: 43) that one of the ways in which this myth is spread and embedded in human consciousness is how the stories of kings with great power and wisdom in the past and then later deified by their grandchildren later. As the Minangkabau proverb that goes "The leader is lifted in status, allowed a step forward. The context of the myth under discussion, the mythologized figure is one of the religious figures of Islam i.e. Imam Ali. Ali's figure has always been described as a wise and brave man of knowledge. In this myth, the glory and virtue of Ali's character, mixed with the myths and legends of the local nuances. As an example of the verbal narrative by Long Nan as follows, where Ali is so mighty, defeated Raje Cine (King of China) in a battle.

2 This theory is derived from the famous mythologist, Euhemeros (circa 320 BC) who argued that the Greek gods and goddesses developed from the legend of humans. 
"Imam Ali fought against King of China, during the war, he nudged a little boy who brought a bottle of kerosene. The kerosene spilled onto the ground. The boy cried. Seeing the boy crying, Sayyidina Ali extorted the land until the kerosene returned into the bottle. As a result of being squeezed, the land (or the earth) was in pain, and vowed not to reject the body of Imam Ali. That's why Imam Ali was not welcome by the earth, so he had no tomb. We all know that there's a tomb of Abu Nawas, in Arabia. By the end of the war, Sayyidina Ali managed to split the head up to the body of King of China, and after the war, he (Ali) threw his sword into red sea. (The story told by Long Nan)

In this context, there are several aspects of the study. First, the mythological orientation of the characters; second, the implications of the myths to the worldviews they believe; third, the benefits of the creation of the myths to those attributed to them. The orientation of the mythologization of the figures shows how Ali's character has always been linked to something of a certain great power ${ }^{3}$. Sayyidina Ali in the public worldview is symbolized as a friend of the Prophet Muhammad who had courage, rather than as a friend who had the intelligence and broad knowledge. The mythology of Imam Ali's wisdom is also found in several places in the archipelago, such as in West Java and Sumatra.

\section{Mythology of Figure: Cultural Construction in the Frame of Religious Insight Infiltration (syncretism)}

A second analysis that the researchers can explore from the myths of Sayyidina Ali is a form of religious syncretism in the local myth of coastal society. As Clifford Geertz (1981) saw in Javanese Islamic religion, the religion is shrouded by syncretism or mix of religious views with local cultural views, which sometimes contradict each other. The myth of the crocodile and Ali also hinted that there has been an interaction between Islam and local culture. There is a

3 Based on Long Nan's account, Sayyida Ali had a lot of advice, was clever and brave. At one time, these four caliphs were tested by the Prophet by being given each a banana. The four were asked to eat the banana without being noticed or seen. Some Caliphs ate it in the woods, in the sea and some in the cave. Sayyidina Ali did not eat his banana. When asked why he did not eat it, Sayyidina Ali answered, "How would I eat it, am not I a person too? This version of the story was never heard of before, because usually a similar story is often brought by preachers to convey a moral message about virtue, but the setting is usually between the students and kyai. Another story, the contest to win Fatimah. The companions were required to complete reciting the Quran in one night. All the companions were competing to read the Quran, while Ali chose to sleep. When awake in the dawn, the other companions were still reading the Quran, some of them had only 1 or 2 juz left. Ali got up and only read Al-Fatihah three times. And Ali was then considered a winner, since al-Fatihah is the essence of the Qur'an. This version of the story is also somewhat different from that typically conveyed by a preacher, i.e. not surah al Fatihah, but al-Ikhlas 
deviation as a result of a thorough understanding of the history of Islam, thus forming a syncretic understanding pattern. Syncretism sociologically usually serves to "keep" the tradition in a society alive and developing well. Usually, syncretism in religious belief is an attitude or view that does not question the truth or error of a religious view. Quoting Simuh, Sutiyono (?) explain that people who hold to syncretism, all religions are considered good and right. Indirectly, Simuh wanted to say that in the religious view of syncretism, the most important is to maintain harmony between various parties, not on the essence of religious truth. This is in line with Sutiyono's research on syncretism in Trucuk Klaten society in Central Java (research in 2006). Thus, the function of syncretism is to maintain relations between various walks of life in harmony.

Therefore, in the context of the myth of Sayyidina Ali, this is not in the context of religious truth, but it may be to keep the existing social beliefs and social balance in the community including a balance between physical life and metaphysics, man and nature, or the real world and the unseen world like the myth of twin crocodiles, where in the myth builds a connection between human nature and the occult (crocodile). So it is necessary to maintain and respect "relations" with relatives believed to exist in the river. So there are similarities, the myth does not attach importance to the substance of the truth of the story, as well as with syncretism, which is also not concerned with the truth of religious teachings.

\section{Mythology of Figure: Conservation Agenda in the Cover of the Myth of Figure}

The study of crocodile myths of Sayyidina Ali's illegitimate child implicitly also implies a connection between character and the environment. In the context of this study, the environment in question is a river or river area. Because crocodiles are a reptile fauna that can live in two worlds, and exist only in watersheds, not seas. The myths of illegitimate child crocodile and twin crocodiles contain the context of relationship between humans and the environment. The researchers view that the myths and cultural traditions of a society usually contain a cosmological view of the world in which they are located which includes relationship they construct between human life and the physical world and metaphysics around them. Educational values in the Robo'-Robo' Ceremony 'show how it was initiated for salvation for life at sea. It implicitly contains a message to preserve marine life (Hermansyah \& Ar., 2003). It is also said that there are four functions of myths, one of which is the pedagogical (educational) function that myths teach humans about how they should live in every condition. The context of the crocodile myth attributed to Sayyidina Ali teaches that humans must "respect" or preserve the fauna of the river, one of them is the crocodile. 
This myth is similar to that found in ethnic Dayak Ngaju where there are 2 highest god figures in the community, namely Mahatala and Jata. Mahatala has several titles such as Hatala, Lahatala, Mahatara, Bahatara Guru and the original title is Tingang i.e. hornbill. Jata also has other nicknames such as Tambon, Bawin, Jata balawang bulau (jata female with the first door). The Mahatala god dwells in the upper world much better than the human world. Meanwhile, Jata resides in the underworld with his subject the crocodiles. The point that attracted the attention of the researchers is that in ethnic Dayak Ngaju, there is a belief that the crocodile is a sacred animal, so it should not be killed.

Similarly, the legends found among the people of Papua are Towjatuwa or Mighty Crocodile. This legends or myths give a very important message that it is imperative not to kill crocodiles, especially those in the Tami River, because they can bring danger to the descedants of Towjatuwa. The Myth of the ethnic Dayak Ngaju, The Legend of Cincin in Olak-olak Kubu, the Legend of Towjatua in Papua and the Tadam Paling Crocodile King in Teluk Pakedai show how the myths believed in a society provide educational messages in order not to exploit and destroy the crocodile habitats. This mythical phenomenon shows the function of the myth which is the spirit of maintaining the nature equalibrium.

\section{RELATION BETWEEN THE MYTHS OF SAYYIDA ALI'S ILLEGITIMATE CHILD CROCODILE AND HATRED AGAINST SHI'A.}

One of the hypotheses to be proved through this research is whether the crocodile myth of Sayyida Ali's illegitimate child has something to do with the hatred of a group toward the spread of Shi'a, with Imam Ali being the main Shiite figure. Based on the data obtained no statements or data (either directly or indirectly) lead to this indication. Based on the available data, there is no hint of hate directed toward religious belief. However, based on the researchers' analysis of the mythical content, the storylines formed, and the attribution of the story to Imam Ali, it implies that there is a negative stereotype directed at Imam Ali. This analysis is "far" beyond the emic perspective of mythical tellers.

Researchers have other opinions, most likely that this myth is not the original of this region, but brought in from other places given there are other versions that are somewhat different from similar objects and subjects elsewhere, both Sumatra and Java. Among the people of Sumatra and West Java, the name Sayyidina Ali is very popular associated with the supernatural power. The saga of Ali's grave on the moon is found in folk tales among Javanese society 
around the palace. As reported by H. Soedarto in an interview, moving on from this belief, it may not have been constructed by local people, but may have come from civilization centers. If this theory is believed to be true, it may be the hatred against Shiite groups that is constructed in this context.

This analysis is based on the views of De Jong (1980) that myths not only contain moral values, but they also serve as a means of maintaining power, hegemony, and domination. This is what De Jong called a political myth. So, consciously or unconsciously, the myth connecting Imam Ali with Crocodile grows indirectly because it is "nurtured" by certain religious authorities, with a diverse array of interests. The history of the conflict between Shia and Sunni recorded that the seeds had appeared after the death of Prophet Muhammad, continued in the Umayyad, Abbasid, Fathimiyah, Safawiah, Iranian Revolutionary periods until the Arab Spring or Arab revolutions. Among the most anti-Shi'a regimes are the Kingdom of Saudi Arabia. From the beginning, the Saudi government was very anti-Shi'a as reported by Ardison Muhammad (as quoted by Sahide, 2013: 322).

In the context of the Indonesian archipelago, KH. Hasyim Asy'ari as the founder of the NU organization also explicitly stated that Shi'a is heretical. It is also said that, KH. Hasyim Asy'ari in his three works of Muqaddimah Qanun Asasi li Jam'iyah Nahdhatul Ulama', Risalah Ahlu al-Sunnah wal Jama'ah, al-Nur al Mubinfi Mahabbati Sayyid al-Mursalin and al-Tibyan fi Nahyi an Muqatha'ah al-Arham wa al-Aqrab wa al-Akhwan, obviously criticized the teachings of Shi'a (both Imami and Zaidiyyah) are a false school. The Shi'a sect is considered a class that denounces the companions of Prophet Muhammad, especially Abu Bakr, Umar and Uthman.

If this text becomes the basis of our analysis, it may be that the myths with hate and cultic content may have flourished in the Sunni region. First, the myth of hatred against Shi'a developed among Sunnis to discredit Shia that is considered heretical. The second possibility is the Sunni-dominated territories have been infiltrated by the Shi'a view over a long period of time because as we all know that the pattern of Islam in the Indonesian archipelago is predominantly Sunni, although in some areas, the view of Shia also developed earlier which gradually began to disappear. However, various views and traditions of Shi'a are still preserved such as the celebration of Ashura on 10 Muharram for example. According to Aboebakar Atjeh (1977: 31), Islam originally in Aceh was originally spread by Indian and Gujarati merchants and preachers of Shafi'i and Shi'a Arabs. This opinion is based on two previous expert opinions of Sayyid Moestafa At-Thabathaba'i and Sayyid Dhiya' Shahab with the work entitled "the Indonesian-Iranian Cultural Relation (Haulal' 
Alaqatith Thaqafiyah Baina Iran wa Indonesia) published in 1339 by the Iranian Cultural Office Jakarta (Atjeh, 1977:32). The opinion of Aboebakar Atjeh confirms that, in addition to living the Sunni tradition, Indonesia also received Shia in the period of spreading Islam in the archipelago. This context may help us understand the process of Islamization, the interaction between Islam and the local culture and the origins of various myths containing socioreligious content.

\section{CONCLUSION}

Based on the analysis of the myths of Sayyina Ali from various perspectives, both sociology and anthropology (as well as sociology and anthropology of religion) the researchers came to several conclusions as follows. First, the myth of Sayyidina Ali's illegitimate child crocodile is characterized with historical myth and myth of origin, with the formation of mythologization on the character of Sayyidina Ali. Euhemerism has occurred that is the stance to the character, in this case the religious figure (Imam Ali) with a very strong syncretic style. The archetype is the identification of Ali as a symbol of might or spiritual power which is expected with the mastery of such power will provide a sense of security for those who believe it. The place of origin and development of the myth took place in coastal areas, where people depend on the natural resources that exist in the sea. The "enemy" that threatens security at the estaury is a crocodile, so the myth is related to how to keep "harmonization" with crocodiles. Second, there has been a syncretism between the local culture of the society and religious views. The accepted religious views are very peripheral, so the local construction of the cultural actors is very dominant namely the setting of an ahistorical story (river, crocodile, coconut trunk, banana leaf in Arab land), that is irrational and even paradox of religious views, denotes the shallow knowledge of religion. Thus, this myth explains the process of syncretism in coastal societies, by not attaching importance to the substance of religious truth, but simply maintaining the harmonization between religion and the concept of local culture (as the native tellers of oral tradition).

Third, Judging from the benefits of the myth, it implicitly contains a message (education) so that humans keep the harmony between human life and nature because, thanks to people's belief in relationship with crocodiles, it makes humans wiser in how they should treat nature or the environment around them. This value is in line with the conservation mission in modern natural resource management concepts. Indirectly, this myth becomes a kind of educational myth, because it indirectly teaches humans to keep harmonizing 
with nature. These values are not arbitrary, but they are practically observed and practiced by the native speakers as found in Kubu and in Teluk Pakkedai. Fourth, in relation to the hypothesis, there is a possibility that this myth reflects negative streotypes against Shi'a, as the researchers believe that there are two possibilities; first, there is an issue of dislike of Shi'a among Sunni Muslims, because some of its teachings are considered deviant. Thus, the myth with a negative content against Shia is deliberately "preserved" as a form of resistance against Shi'a heresy. This opinion is based on the analysis of the dominant Islamic style in the Indonesian Archipelago, including West Kalimantan with its Sunni Islamic traditions. The second possibility is that this myth as a syncretic form of admiration, flourished among the Sunni, but is a residue of the teachings of Shi'a that had been taught in some areas of the Indonesian Archipelago.

\section{REFERENCES}

Abdulroya Panaemalae, A., \& Prasojo, Z. (2016). Islam and the West: Tariq Ramadan and the Discourse of Religion of Peace for a Global Understanding. Al-Albab, 5(2), 237 - 250. doi:https://doi.org/10.24260/alalbab.v5i2.507

Alifuddin, M. (2007). Islam Buton: Interaksi Islam dengan Budaya Lokal. Jakarta: Badan Litbang dan Diklat Departemen Agama RI.

Armstrong, K. (2013). Compassion: 12 Langkah Menuju Hidup Berbelas Kasih. Bandung: Mizan.

Atjeh, A. (1977). Aliran Syiah di Nusantara. Jakarta: Islamic Research Institute.

Baal, J.V. (1987). Sejarah dan Pertumbuhan Teori Antropologi Budaya (hingga dekade 1970-an) Jilid 1. Jakarta: PT. Gramedia.

Budiwanti, E. (2000). Islam Sasak. Yogyakarta: LKiS.

Daeng, H. J. (2000). Manusia, Kebudayaan, dan Lingkungan: Tinjauan Anropologis. Yogyakarta: Pustaka Pelajar.

De Jong, de Josselin, P.E. (1980). "Myth and Non-Myth" in R. Schefold (Ed), Man, Meaning and History: Essays in Honour of H.G. Schulte Nordholt. The Hague: Martinus Nijhoff.

Dhavamony, M. (1995). Fenomenologi Agama. Yogyakarta: Kanisius. 
Florus, P. (eds). (2005). Kebudayaan Dayak: Aktualisasi dan Transformasi. Pontianak: Institut Dayakologi.

Geertz, C. (1981). Santri, Priyayi, Abangan Dalam Masyarakat Jawa. Jakarta: Pustaka Jaya (translation).

Hartanto, J.R. (?). Wujud Sinkretisme Religi Aluk Todolo dengan Agama Kristen Protestan. (unpublished manuscript).

HS, H.S. (?). "Masyarakat Dayak Meratus, Agama Resmi dan Emansipasi”. in Zainul Erfan \& Arriedlo (Eds.). Potret Banjar Dalam Kritik. Banjarmasin: Pusat Studi dan Pengembangan Borneo (PSPB).

Hermansyah \& Ar. E.H. (2003). Nilai-nilai Pendidikan Dalam Upacara Robo'-Robo' (unpublished research report). Pontianak: STAIN Pontianak.

Pelras, C. (2006). Manusia Bugis. Jakarta: Nalar.

Prasojo, Z. (2012). Penguatan Identitas Dayak Muslim Katab Kebahan. AlUlum, 12(2), 245-266. Retrieved from

http://journal.iaingorontalo.ac.id/index.php/au/article/view/100

Putra, H.S.A. (2007). “Mencari Jati Diri dan Identitas Melayu.” Retrieved from http//www: melayu online.com. on 28 September 2007.

Sahide, A. (2013). "Konflik Syiah-Sunni Pasca The Arab Spring. In Jurnal Kawistara. Vol. 3 No. 3, 22 Desember 2013. p. 227-334.

Syam, N. (2005). Islam Pesisir. Yogyakarta: LKiS.

Spradley, J.P. (1997). Metode Etnografi. Yogyakarta: Tiara Wacana.

Sutiyono, (?) Tradisi Maysarakat Sebagai Kekuatan Sinkretisme di Trucuk, Klaten (unpublished manuscript). Yogyakarta: FBS, Universitas Negeri Yogyakarta.

Taum, Y. Y. (2011) Lubuang Buaya: Mitos dan Kontra Mitos. Accessed from: http://www.academia.edu/3231296/LUBANG_BUAYA_MITOS_ DAN_KONTRA-MITOS (on 3 Dec 2014).

Varisco, D.M. (2005). Islam Obscured: The Rhetoric of Anthropological Representation. New York: Palgrave MacMillan.

Wiyata, L. (2002). Carok, Konflik Kekerasan dan Harga Diri Orang Madura. Yogyakarta: LkiS.

Yulianto, J. (?). Teori Struktur Levi Strauss terhadap Mitos Raja Malwopati. Accessed from http://pascaunesa2011.blogspot.com/2012/06/teori-struktur-levi-strauss-terhadap.html (on April 2014). 